Bartın Üniversitesi

Eğitim Fakültesi Dergisi

Cilt 6, Sayı 1, s. 346-364, Subat 2017

BARTIN - TÜRKIYE

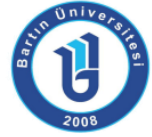

ISSN: 1308-7177
Bartin University

Journal of Faculty of Education

Volume 6, Issue 1, p. 346-364, February 2017

BARTIN - TURKEY

\title{
Ortaöğretim Öğrencilerinin, Dijital Oyunların İngilizce Kelime Öğrenimine Katkısına Yönelik Görüşleri
}

Sibel CEYLANER; İngilizce Öğretmeni, Barbaros Ortaokulu, sibelceylaner@outlook.com

Tuğba YANPAR YELKEN; Prof.Dr, Mersin Üniversitesi, tyanpar@gmail.com

Öz: Bu araştırmanın amacı, ortaöğretim öğrencilerinin dijital oyunların kelime öğrenimine katkısına yönelik görüşlerini belirlemektir. Araştırmanın örneklemini 2014-2015 öğretim yılında, Mersin ili, Silifke ilçesindeki üç farklı okul türündeki altı farklı ortaöğretim kurumunda okuyan toplam 250 öğrenci oluşturmuştur. Araştırma, verilerin analizine dayalı betimsel bir çalışmadır. Araştırmanın verileri araştırmacı tarafından geliştirilen anket yoluyla elde edilmiştir. Veriler değerlendirildiğinde, öğrencilerin en çok yarış ve aksiyon/serüven türünde oyunları tercih ettikleri, dijital oyunları genelde stres atma ve zaman geçirme amacıyla oynadıkları saptanmıştır. Hızla gelişen teknolojiyle oyunlara en çok akıllı telefonlar aracılığıyla ulaştıklarını belirten öğrencilerin çoğunluğu dijital oyunların kelime öğrenimine ve iletişime katkı sağladığına dair olumlu görüş belirtmiştir.

Anahtar Kelimeler: dijital oyunlar, yabancı dil öğrenimi, kelime öğrenimi, teknoloji

\section{Views of Secondary School Students on the Contributions of Digital Games to Their Vocabulary Knowledge in English}

\begin{abstract}
The aim of this study is to investigate the views of secondary school students on the contributions of digital games to their vocabulary knowledge in English. This research is a descriptive study examining the research questions based on the analysis of qualitative data. Data of the study were collected through questionnaire applied in six secondary school students(250 students) in Silifke, Mersin the academic year of 2014-2015. The results indicated that students mostly prefer racing and action / adventure type of games. It was found that digital games are usually played in order to spend free time and blow off steam. Most of students usually get through smart phones to play games and state a positive opinion that digital games contribute to their knowledge of English Vocabulary and communication in English.
\end{abstract}

Key Words: digital games, language learning, vocabulary learning, technology. 


\section{GíRiş}

Oyun, her birey için vazgeçilmez bir kavramdır. İnsanlık tarihi kadar eski ve süreklilik gösteren bir aktiviteolan oyunun insanın gelişimine olan etkileri henüz kapsamlı bir şekilde açıklanmış değildir. Her yaş grubundan bireyi ilgilendiren bir etkinlik olarak görülen oyun ile ilgili görüşler, bilimsel çalışma ve bulgularla birlikte önemini artırmışve bazı bilim adamlarını bu alana yönlendirmiştir. Oyun kavramı farklı şekillerde tanımlanmaktadır. Türk Dil Kurumu oyunu "yetenek ve zekâ geliştirici, belli kuralları olan, iyi vakit geçirmeye yarayan eğlence" veya "bedence ve kafaca yetenekleri geliştirmek amacıyla yapılan, çevikliğe dayanan her türlü yarışma" olarak tanımlamaktadır (TDK, 2010). Bu alanda yapılan en kapsamlı tanımlardan biri Fransız sosyolog Roger Caillois (1957) tarafından yapılmıştır. Bu tanıma göre oyun, eğlenmek için yapılan, belirli bir alan ve zamanda sürdürülen, beklenmeyen sonuçları ve kuralları olan, gerçek hayattan farklı olduğu bilinciyle gönüllü yapılan bir etkinliklerdir. Zamanla bu etkinlikler teknolojideki gelişmelerle birlikte dışarıdan iç ortamlara taşınmıştır.

Teknolojinin gelişmelerle yaşamımıza giren en önemli araçlardan biri olan bilgisayarlar, günümüz dünyasının en gelişmiş araçlarındandır ve hayatımızın her alanında etkileri görülmektedir. Bilgisayarların ortaya çıkışlarından kısa bir süre sonra bilgisayar oyunlarıyla da tanıştığımızı görürüz (Durdu, Tüfekçi ve Çağıltay, 2005). Teknolojinin hayatımıza kattığı bu kavram zaman ilerledikçe geniş kitlelerce kabul görmeye başlamış ve yaygınlaşmıştır. Elbette bu kavramın yaygınlaşması süresince olumlu ve olumsuz algılar oluşmuştur. Örneğin oyunlar sanat dünyası tarafından kabul görmemektedir, çünkü halk hala oyunları çocuk oyuncağı olarak görmektedir (Martin,2007). Benzer şekilde, bilgisayar oyunları da "kendini tatmin etme" ya da "zaman öldürme" aracı olarak algılanmaktadır. Ancak çok büyük kitleler tarafından tercih edilen bu oyunlar zamanla karşımıza olumlu algılarıyla da çıkmaya başlamıştır.

Oyunların ulaştığı kitleler ve oyuna ayrılan zaman göz önüne alındığında aslında oyun dünyasının her yaştan insan için vazgeçilmez unsurlardan biri haline geldiği gözlemlenmektedir. Sürekli gelişen teknolojinin etkisiyle oyun kavramı, teknolojik araçlarla farklı şekillerde karşımıza çıkmaktadır. Gelişen teknoloji ile farklı cihazlar ile hayatımıza giren bu tarz oyunlar zamanla "video oyunları", "mobil oyunları" ve "bilgisayar oyunları" terimleri olarak birbirlerinin yerine dönüşümlü olarak kullanılmışlardır (Kirriemuir, 2002). Ancak, günümüzde yeni teknolojik gelişmelerle dönüşüm geçiren oyunlar konsol sistemler aracılığıyla yerini yeni oyun kültürüne bırakmıştır. Bu yeni oyun kültürü “dijital oyun” olarak ifade edilmektedir.

Dijital oyun sektörünün tarihi, analog ekran üzerindeki basit uygulamalar esas alınarak 1940'lı yıllara dayandırılmaktadır. Ancak modern anlamda örnekler ancak 1970'li yıllarda ortaya çıkmıştır. 1970'li yıllarda dijital oyunlar genellikle bilimsel deneyler için kullanılmış ve daha sonra 1980'li yıllarda popüler bir akım haline gelmiştir. 1990'lı yıllarda dijital oyunlar sektörleşmiştir. Elbette sadece teknolojik gelişmeler değil ekonomik, kültürel hatta politik gelişmeler bile dijital oyunların çeşitlenmesinde etkili olmuştur. Türlerine göre sınıflandırılmak istendiğinde birçok alt dalı olmasına karşın dijital oyunlar; macera, aksiyon, rol yapma, strateji, simülasyon, spor, dövüş ve online oyunlar şeklinde ayrılır (Türkiye Dijital Oyunlar Federasyonu raporu, 2012).

Dünyada bir milyarın üzerinde, Türkiye'de 20 milyonu geçen insan dijital oyun oynamaktadır ve insanlar giderek daha küçük yaşlarda (5-6 yaş) oyunla tanışmaktadırlar (Türkiye Dijital Oyunlar Federasyonu raporu, 2012). Dijital oyunlara bu kadar erken yaşlarda başlanıyor olması elbette akla bunların etkilerini getirmektedir. Oyun yaşının düşmesi ve bağımlılık gibi genellikle çocuk gelişimindeki olumsuz etkileri ön plana çıkartılsa da dijital oyunların çok sayıda akademik çalışma ile çocukların zihinsel gelişimine, el göz koordinasyonuna yardımcı olması da dâhil olmak üzere önemli miktarda olumlu etkilerinin 
olduğu da tespit edilmiştir. Oyunların belli bir yere kadar, çocuğun gelişim aşamasında içgüdüsel başarma ve ilerleme, gelişme intiyacını giderdiği, problem çözme ve çoklu görev yetisini kuvvetlendirdiği bulunmuştur (Tüzün, 2006).

Eğitmenlerin ve ebeveynlerin en büyük kaygılarından birisi dijital nesillerin zamanlarının çoğunu bilgisayar ve oyun konsollarının başında geçirmeleridir. Dijital oyunların zararlarından ve bağımlılık yapmasından bahseden ve bu konuda kaygı duyan birçok araştırmacı ve eğitmen vardır ve genellikle dijital oyunların olumsuz taraflarına odaklanmaktadırlar (Griffiths, 2002; Gee, 2007; Steinkuehler, 2010). Saatlerce oynanan dijital oyunlar çoğu zaman ebeveynler tarafından hoş karşılanmayan bir durumdur ve ebeveynler böyle durumlarda genellikle dijital oyunların zararlı olduğunu düşünmektedirler (Griffiths, 2002; Gee, 2007; Steinkuehler, 2010). Bavelier (2012), hayatta her şey gibi dijital oyunlarında standart olmadığını iyi kalitede veya kötü kalitede oyunlar olabileceğini belirtmiştir. Bavelier'e göre (2012), dijital oyunların öğrenme, dikkat ve görsellik gibi beynimizin gelişmesine yardımcı olan unsurlara sahip olduğunu ve bu durumun avantaja çevrilmesi gerekmektedir.

Dijital oyunların algısal, dikkat ve bilişsel süreçlere katkısını fark eden firmalar da artık oyun tasarımlarını sadece eğlence amaçlı normal kullanıcılar için değil, eğitim sektörü içerisindeki potansiyel kullanııılar içinde üretmeye başlamıştır. Örneğin, Nintendo (2008) firması yeni tasarladığı bir oyunda düşünme, hatırlama, analiz etme, hesaplama ve tanımlama kategorilerinde beynimizi eğitebileceğimiz Big Brain Academy isimli oyunu tanıtmıştır.

Tüm bu gelişmelerle birlikte, eğitimde başarı kavramı ve beceriler teknolojiyle beraber tekrar sorgulanmaya başlamıştır. Tor (2004), çağdaş toplumda başarılı bir öğrencinin sahip olması gereken becerileri şöyle sıralamaktadır; Bilgi teknolojilerindeki araçları ustalıkla kullanabilme, veri toplama, yorumlama ve bu verileri kullanabilme. Bu becerilerin yanı sıra yabancı dil öğrenimini oluşturan temel kavramların da dil becerileri edinimi olduğu düşünülürse buna ayak uydurabilen bireylerin başarıya ulaşmaları kolaylaşacaktır. Tüm bu becerilerin kazanılmasında elbette ki dijital oyunların etkisini göz ardı etmek mümkün değildir.

Yabancı dil öğreniminde dijital araçlar giderek yaygınlaşmakta ve etkisini arttırmaktadır. Bireye çoklu öğrenme ortamı sunan bu araçların, evrenselleşmiş oyunlarla dil öğrenimine katkı sağlayıp sağlayamayacağı merak uyandırmıştır. Yabancı dil öğrenen kimse, o dildeki becerileri kazanırken oyunun içeriklerinden yararlanarak bunu daha kolay ve eğlenceli hale getirebilir. Öğrencilerin dijital ortamları genelde oyun kültürü üzerinden takip ettikleri de göz önüne alınırsa en çok etkileşimi bu alanda gösterdikleri fark edilmektedir.

Son zamanlarda dijital oyunlar, birçok araştırmacı tarafından eğitimde kullanılabilecek potansiyel bir öğrenme aracı olarak görülmektedir. Önceden bilgisayar oyunu olarak ifade edilen ve günümüzde yerini dijital oyuna bırakan bu kavram yabancı dil kelime öğrenimini geliştirmede faydalı mıdır? Bir eğitim aracı olarak kullanılabilir mi? Bu çalışmada, dijital oyunların bir öğrenme aracı gibi kullanılıp kullanılamayacağına, dijital oyunların eğitim sürecinde faydalarının olup olmadığına dair öğrenci görüşlerine yer verilmiştir. Araştırma ilezamanla daha erken yaşlarda oynanmaya başlanan dijital oyunların, yabancı dil becerileri üzerinde etkisi olup olmadığını tespit ederek, öğrencilerin kelime öğrenimlerini nasıl etkilediği hakkındaki görüşlerine ulaşmak amaçlanmıştır.

\subsection{Problem Cümlesi}

'Ortaöğretim öğrencilerinin dijital oyunların, kelime öğrenimine katkısı hakkındaki görüşleri nelerdir?' 


\subsubsection{Alt Problemler}

1. Ortaöğretim öğrencilerinin teknolojik alt yapı ve dijital oyunlara ilişkin mevcut durumları nelerdir?

2. Dijital oyunların kelime dinleme becerisine katkısına yönelik ortaöğretim öğrencilerinin görüşleri nelerdir?

3. Dijital oyunların kelime konuşma (telaffuz?) becerisine katkısına yönelik ortaöğretim öğrencilerinin görüşleri nelerdir?

4. Dijital oyunların kelime okuma becerisine katkısına yönelik ortaöğretim öğrencilerinin görüşleri nelerdir?

5. Dijital oyunların kelime yazma becerisine katkısına yönelik ortaöğretim öğrencilerinin görüşleri nelerdir?

6. Ortaöğretim öğrencilerinin dijital oyunların kelime öğrenimine katkısına ilişkin görüşlerinde cinsiyete bağlı anlamlı bir farklılık var mıdır?

7. Ortaöğretim öğrencilerinin dijital oyunların kelime öğrenimine katkısına ilişkin görüşlerinde okul türüne bağlı anlamlı bir farklılık var mıdır?

8. Dijital oyun oynayan ortaöğretim öğrencilerin oyunlardan en çok edindikleri kelime grubu hangileridir?

\section{YÖNTEM}

Bu araştırmada, ortaöğretim öğrencilerinin dijital oyunların, kelime öğrenimine katkısı hakkındaki görüşlerini incelenmiştir. Araştırma, nicel ve nitel verilerin analizine dayalı araştırma sorularını incelemeye yönelik yapılmış betimsel bir çalışmadır. Betimsel çalışmalar mevcut durumu ortaya çıkarmaya yarayan çalışmalardır (Erkuş, 2013; Çepni, 2009). Betimsel modelle, bir konudaki hali hazırdaki durum araştırılır. Katılımcılardan, anketler aracılığıyla yazılı olarak bilgi alınabileceği gibi, görüşmeler yoluyla sözlü olarak da bilgi toplanabilir (Özdamar, 1999).

\subsection{Evren ve Örneklem}

Araştırmanın evrenini Mersin ili Silifke ilçesindeki ortaöğretim kurumlarında 2014-2015 öğretim yılında öğrenim gören öğrenciler oluşturmaktadır. Araştırmaya esas örneklem grubu, amaçlı örnekleme yöntemine uygun olarak belirlenmiştir. 2014-2015 öğretim yılı, Mersin ili, Silifke ilçesindeki ortaöğretim kurumlarından 3 (üç) farklı okul türüne ait 6 (altı) farklı okul seçilmiş ve bu okullarda okuyan öğrencilerin dijital oyunların kelime öğrenimine katkısına ilişkin görüşlerini saptamaya yönelik araştırma yürütülmüştür. Araştırma için seçilen okul türleri; Anadolu Lisesi, Meslek Lisesi ve Özel Lisedir. Tablo 1'de araştırmaya katılan öğrencilerin okudukları okul türlerine ve cinsiyetlerine göre dağııımları verilmiştir.

Tablo 1

Araştırmaya Katılan Öğrencilerin Okudukları Okul Türlerine ve Cinsiyetlerine Göre Dağıımı

\begin{tabular}{ccccc}
\hline & & & \multicolumn{2}{c}{ Cinsiyet } \\
\cline { 3 - 5 } Okuduğu Okul Türü & Öğrenci Sayısı & Yüzde & Kız & Erkek \\
& $f$ & $\%$ & $f$ & $f$ \\
\hline Meslek Lisesi & 90 & 36.0 & 25 & 65 \\
\hline Anadolu Lisesi & 60 & 24.0 & 25 & 35 \\
\hline Özel Lise & 100 & 40.0 & 49 & 51 \\
\hline TOPLAM & 250 & 100.0 & 99 & 151 \\
\hline
\end{tabular}

Araştırmaya, toplam 250 öğrenci katılmış, bu öğrencilerin \% 60.4 'ünü erkek, \% 39.6 'sını de kız öğrenciler oluşturmaktadır. 


\subsection{Veri Toplama Araçları}

Araştırmada veri toplama aracı olarak, araştırmacı tarafından geliştirilen anket formu kullanılmıştır. Yapılacak bir araştırmadan istenilen sonuçların elde edilebilmesi için konuya uygun soruların seçilmesi ve bunların soru kâğıdı üzerinde uygun biçimde düzenlenmesi çok önemlidir. (Balcı, 1985). Anketin en kuvvetli yönü, uygun durumlarda, geniş bir gruptan, çok miktarda veriyi, kısa zamanda toplama olanağı yaratmasıdır. Özellikle kapalı uçlu sorularla yapılan anketlerde, cevapların belli sınırlar içinde toplanabilmesi mümkündür. ( Karasar, 2003).

$\mathrm{Bu}$ araştırmada uygulaması planlanan anket maddelerinin belirlenmesi için öğrenciler için açık uçlu sorulardan oluşan bir form hazırlanmış, bu form rastgele seçilen bir grup ortaöğretim öğrencisine uygulanmış ve anket maddeleri öğrencilerin cevapları doğrultusunda ve ilgili alınyazın incelenerek oluşturulmuştur. Böylelikle öğrenilmek istenen görüşlere yönelik uygun maddelerin seçilmesi sağlanmış ve maddeler alınyazından da faydalanılarak doğru bir anket formatında hazırlanmıştır. Yapılan bu ön çalışma sonrasında öğrencilere aşağıdaki 4 bölümden oluşan anket uygulanmıştır.

1. Bölüm: Kişisel Bilgiler

2. Bölüm: Dijital Oyunlara Yönelik Anket Soruları

3. Bölüm: Dijital Oyunların Kelime öğrenimine Katkısına Yönelik Sorular

4. Bölüm: Açık Uçlu Sorular

Anketi oluşturan maddeler için kullanılan cevap seçenekleri, likert tipinde 5'er basamaktan oluşmuştur. Olumludan olumsuza doğru "Kesinlikle Katılıyorum", "Katılıyorum", "Kararsızım", "Katılmıyorum", "Kesinlikle Katılmıyorum" şeklinde hazırlanan seçenekler yardımıyla ölçek cevaplanmıştır. Ölçeğin geçerlik ve güvenirliğinin belirlenmesinde ilk olarak güvenirlik katsayısı olan Cronbach's Alpha katsayısı hesaplanmıştır. Alpha güvenirlik katsayısı, 0.78 olarak gerçekleşmiştir.

Anketi oluşturan maddelerin, öğrenilmek istenen görüşleri belirlemede nicelik ve nitelik olarak yeterli olup olmadığını tespit etmek için Eğitim Programları ve Öğretim alanından 4 (dört), Eğitimde Ölçme ve Değerlendirme alanından 2 (iki) uzmanın görüşüne başvurulmuştur. Uzmanlardan anketin taslak formunda yer alan maddeleri kapsam geçerliliği açısından değerlendirmeleri istenmiştir. Araştırmada ayrıca ankete katılanların ek yorumlarına intiyaç duyulmuştur. Burada cevaplayıcılara, kendileri için önemli olanları ve istediklerini kendi cümleleriyle yazabilmeleri için boş bir alan bırakılmış ve açık uçlu soru türleri kullanılmıştır. Ölçme aracının uygulanması aşamasında, araştırma için hazırlanan anket öğrencilere kendi okullarında araştırmacı tarafından uygulanmıştır.

\subsection{Verilerin Çözümlenmesi}

Araştırmada elde edilen nicel verilerin analiz edilmesi için SPSS programından yararlanılmıştır. Araştırma verilerinin boxplot analizi ve normallik testi yapılmış, uç değerlerin olmadığı tespit edilmiştir. Değerler $0.05^{\prime}$ den büyük olduğu için verilerin normal dağıldığı gözlenmiştir. Veriler, öğrencilerin cinsiyetleri, okudukları okullar karşılaştırılarak çözümlenmiş ve yorumlanmıştır. Araştırmada, incelenen değişken açısından gruplar arasında farklı koşullar altındaki tepkilerinde, farklılığın olup olmadığının incelenmesine yönelik olarak bağımsız gruplar için $\mathbf{t}$ testi uygulanmıştır. Kız ve erkek öğrencilerden oluşan 250 öğrenciye yöneltilen anket maddeleri karşılaştırılarak aralarında anlamlı bir fark olup olmadığı ve aradaki farkın rastlantısal mı, yoksa istatistiksel olarak anlamlı mı olduğuna karar verilmiştir. Küçük örnekleme teorisi olarak da bilinen $\mathrm{t}$ dağımı, bu araştırmadaki küçük örneklemle de çalışmaya imkân verdiğinden, araştırma için büyük kolaylık sağlamıştır. Araştırmaya dâhil edilen 3 (üç) tür okul 
grubu bulunmaktadır. Bu okul türlerindeki öğrencilerin anket maddelerinde belirttikleri görüşleri arasında fark olup olmadığını istatistiksel olarak analiz etmek için ANOVAkullanılmıştır.

\section{BULGULAR}

$\mathrm{Bu}$ araştırmada ortaöğretim öğrencilerinin, dijital oyunların, kelime öğrenimine katkısına yönelik görüşlerini belirlemek amaçlanmış ve aşağıda verilen bulgulara ulaşılmıştır.

\subsection{Ortaöğretim Öğrencilerinin Teknoloji ve Dijital Oyunlara İlişkin Mevcut Durumları}

Tablo 2' de araştırmaya katılan öğrencilerin internet bağlantısına sahip olma oranları verilmiştir.

Tablo 2

Araştırmaya Katılan Öğrencilerin Internet Bağlantısına Sahip Olma Oranları

\begin{tabular}{ccc}
\hline İnternet & Öğrenci Sayısı & Yüzde \\
Bağlantısına Sahip Olma & $f$ & 69 \\
\hline Evet & 173 & 69.2 \\
\hline Hayır & 67 & 26.8 \\
\hline Belirtmeyen & 10 & 4 \\
\hline TOPLAM & 250 & 100
\end{tabular}

Araştırmaya katılan ortaöğretim öğrencilerin \% 69.2' si evlerinde internet bağlantısı olduğunu belirtirken, \% 26.8' i internet bağlantısı olmadığını belirtmiştir. Araştırmaya katılan öğrencilerin yüzde $4^{\prime}$ ü internet bağlantısı olup olmadığına dair bilgi vermemiştir.

Tablo 3'de araştırmaya katılan öğrencilerin dijital oyun oynama sıklığı verilmiştir.

Tablo 3

Öğrencilerin Dijital Oyun Oynama Sıklıkları

\begin{tabular}{ccc}
\hline Dijital Oyun Oynama Sıklığı & $\begin{array}{c}\text { Öğrenci Sayısı } \\
\text { Yüzde } \\
\end{array}$ & $\begin{array}{c}\text { Y } \\
\text { Haftada en az 1-2 saat }\end{array}$ \\
\hline Haftada en az 3-4 saat & 90 & 36.0 \\
\hline Haftada 6 saatten fazla & 80 & 32.0 \\
\hline Haftada en az 5-6 saat & 44 & 17.6 \\
\hline TOPLAM & 33 & 13.2 \\
\hline Araştırmaya & 247 & 98.8 \\
\hline
\end{tabular}

Araştırmaya katılan öğrencilerin \% 36'sı dijital oyunları haftada en az 1-2 saat oynadığını belirtirken, \%32' si haftada en az 3-4 saat, \% 17.6' sı haftada 6 saatten fazla oynadığını belirtmiştir.

Tablo 4'te araştırmaya katılan öğrencilerin oynadıkları dijital oyunlara göre dağııımları verilmiştir. 
Tablo 4

Öğrencilerin Oynadıkları Dijital Oyun Türleri

\begin{tabular}{|c|c|c|}
\hline Dijital Oyun Türleri & $\begin{array}{c}\text { Öğrenci Sayısı } \\
f\end{array}$ & $\begin{array}{c}\text { Yüzde } \\
\%\end{array}$ \\
\hline Yarış & 119 & 47.6 \\
\hline Aksiyon/Serüven & 119 & 47.6 \\
\hline Strateji & 102 & 40.8 \\
\hline Spor & 101 & 40.4 \\
\hline Bilgi Yarışması & 73 & 29.2 \\
\hline Simülasyon & 63 & 25.2 \\
\hline Bulmaca & 52 & 20.8 \\
\hline Platform Oyunları & 36 & 14.4 \\
\hline FRP Oyunları(Rol Yapma & 24 & 9.6 \\
\hline \multicolumn{3}{|l|}{ Oyunları) } \\
\hline Diğer & 12 & 4.8 \\
\hline
\end{tabular}

Araştırmaya katılan öğrenciler oynadıkları dijital oyun türünü belirtirken en çok yarış (\%47.6) ve aksiyon/serüven (\%47.6) türünde oyunları tercih ettiklerini belirtirken bunları sırayla strateji(\% $\mathbf{4 0 . 8}$ ) ve spor (\%40.4) türündeki oyunlar takip etmiştir.

Tablo 5' de araştırmaya katılan öğrencilerin dijital oyunları oynama nedenlerine ait dağııım verilmiştir.

Tablo 5

Öğrencilerin Dijital Oyun Oynama Nedenleri

\begin{tabular}{lcc}
\hline Dijital Oyun Oynama Nedenleri & $\begin{array}{c}\text { Öğrenci Sayısı } \\
f\end{array}$ & $\begin{array}{c}\text { Yüzde } \\
\%\end{array}$ \\
\hline Stres Atma & 182 & 72.8 \\
\hline Zaman Geçirmek & 181 & 72.4 \\
\hline Sosyal İletişim & 83 & 33.2 \\
\hline Meydan Okuma & 82 & 32.8 \\
\hline Merak & 61 & 24.4 \\
\hline Düşsel Ortamlar & 34 & 13.6 \\
\hline Diğer & 15 & 6.0
\end{tabular}

Araştırmaya göre öğrencilerin dijital oyunları oynama amaçları sorulduğunda en çok işaretledikleri seçenekler stres atma (\%72.8) ve zaman geçirmek (\%72.4) olmuştur. Öğrencilerin \%33.2'si sosyal iletişim için oyun oynadığını belirtirken, \%32.8' i meydan okuma duygusuyla oyun oynadığını işaretlemiştir.

Tablo 6'da araştırmaya katılan öğrencilerin dijital oyunları hangi teknolojik araçlarla oynadıklarına dair dağılım yer almaktadır.

Tablo 6

Öğrencilerin Dijital Oyun Oynadıkları Teknolojik Araç

\begin{tabular}{ccc}
\hline Kullanılan Teknolojik Araç & $\begin{array}{c}\text { Öğrenci Sayısı } \\
f\end{array}$ & $\begin{array}{c}\text { Yüzde } \\
\%\end{array}$ \\
\hline Akıllı Telefon & 199 & 79.6 \\
\hline Laptop & 104 & 41.6 \\
\hline Ev Bilgisayarı & 95 & 38.0 \\
\hline Tablet & 70 & 28.0 \\
\hline Oyun Konsolu & 67 & 26.8 \\
\hline Netbook & 8 & 3.2 \\
\hline Diğer & 4 & 1.6
\end{tabular}


Tablo 7'ye göre, araştırmaya katılan öğrencilerin dijital oyunları en çok akıllı telefonları (\%79.6) aracılığıyla oynadıkları sonucuna ulaşıımıştır. En az kullanılan dijital oyun aracı olarak netbook (\%3.2) işaretlenmiştir.

Tablo 7'de araştırmaya katılan öğrencilerin dijital oyunları oynarken tercih ettikleri dil seçeneği dağııımı verilmiştir.

Tablo 7

Öğrencilerin Dijital Oyun Oynarken Tercih Ettiği Dil Seçeneği

\begin{tabular}{ccc}
\hline Tercih Edilen Dil Seçeneği & $\begin{array}{c}\text { Öğrenci Sayısı } \\
f\end{array}$ & $\begin{array}{c}\text { Yüzde } \\
\%\end{array}$ \\
\hline İngilizce & 210 & 84 \\
\hline Türkçe & 38 & 15.2 \\
\hline Diğer & 2 & 0.8 \\
\hline TOPLAM & 250 & 100.0 \\
\hline
\end{tabular}

Tablo 7 incelendiğinde, dijital oyunları hangi dil tercihinde oynadıkları sorulan öğrencilerin \% 84' ü İngilizce seçeneğini belirtirken, \% 15.2' si Türkçe dil seçeneğini işaretlemiştir. Diğer seçeneğini işaretleyen 2 öğrenci, dil seçeneği olarak oynadıkları oyunun formatı gereği Rusça oynadıkları belirtmişlerdir.

\subsection{Dijital Oyunların, Kelime Dinleme Becerisine Katkısına iliş̧in Ortaöğretim}

\section{Öğrencilerinin Görüşleri}

Tablo 8' de araştırmaya katılan öğrencilerin dinleme becerisine yönelik anket maddelerine verdikleri cevapların frekans ve yüzdeleri verilmiştir.

Tablo 8

Öğrencilerin Dinleme Becerisine Yönelik Anket Maddelerine Verdikleri Cevapların Yüzdeleri

\begin{tabular}{|c|c|c|c|c|c|}
\hline \multirow[t]{3}{*}{ Anket Maddeleri } & 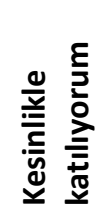 & 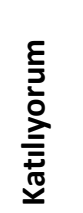 & $\begin{array}{l}\frac{E}{N} \\
\frac{N}{\bar{N}} \\
\frac{\sqrt{\pi}}{\pi}\end{array}$ & 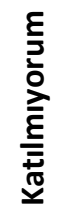 & 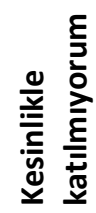 \\
\hline & $f$ & $f$ & $f$ & $f$ & $f$ \\
\hline & $\%$ & $\%$ & $\%$ & $\%$ & $\%$ \\
\hline \multirow{2}{*}{$\begin{array}{l}\text { 1-Oynadığım dijital oyunlardaki sesli komutları/yönergeleri } \\
\text { anlayabiliyorum. }\end{array}$} & 80 & 115 & 44 & 8 & 2 \\
\hline & 32.0 & 46.0 & 17.6 & 3.2 & 0.8 \\
\hline \multirow{2}{*}{$\begin{array}{l}\text { 2- Dijital oyunlardaki karakterlerin konuşmalarını } \\
\text { anlayabiliyorum. }\end{array}$} & 54 & 97 & 74 & 23 & 2 \\
\hline & 21.6 & 38.8 & 9.6 & 9.2 & 0.8 \\
\hline \multirow{2}{*}{$\begin{array}{l}\text { 3- Dijital oyunları sık oynamak kelimeleri anlamamı } \\
\text { kolaylaştırmıyor. }\end{array}$} & 5 & 9 & 2 & 102 & 68 \\
\hline & 2.0 & 3.6 & 24.8 & 40.8 & 7.2 \\
\hline \multirow{2}{*}{$\begin{array}{l}\text { 4- Oynadığım dijital oyunlarda duyduğum kelime telaffuzları } \\
\text { aklımda kalıcı oluyor. }\end{array}$} & 96 & 96 & 45 & 10 & 3 \\
\hline & 38.4 & 38.4 & 18.0 & 4.0 & 1.2 \\
\hline \multirow{2}{*}{$\begin{array}{l}\text { 5- Önceden yanlış telaffuz ettiğim bazı kelimelerin doğru } \\
\text { söylenişini dijital oyun esnasında duyup öğreniyorum. }\end{array}$} & 90 & 106 & 40 & 9 & 5 \\
\hline & 36.0 & 42.4 & 16.0 & 3.6 & 2.0 \\
\hline
\end{tabular}

Tablo 9 incelendiğinde, öğrencilerin çoğunluğu, dinleme becerisine yönelik anket maddelerine verdikleri cevaplarda, oynadıkları dijital oyunlardaki sesli komutları ve konuşmaları anlayabildikleri, duydukları kelimelerin telaffuzunun akıllarında kalıcı olduğu ve 
kelimelerin söylenişini doğru dinleyip öğrendikleri yönünde olumlu görüş belirtmişlerdir. Oyunları sık oynamanın kelimelerin kalııılığını ve kolaylığını arttırmadığına da katılmadıklarını belirtmişlerdir.

\subsection{Dijital Oyunların, Kelime Konușma Becerisine Katkısına Yönelik Ortaöğretim} Öğrencilerinin Görüşleri

Tablo 9 'da araştırmaya katılan öğrencilerin konuşma becerisine yönelik anket maddelerine verdikleri cevapların frekans ve yüzdeleri verilmiştir.

Tablo 9

Öğrencilerin Konuşma Becerisine Yönelik Anket Maddelerine Verdikleri Cevapların Yüzdeleri

\begin{tabular}{|c|c|c|c|c|c|}
\hline \multirow[t]{3}{*}{ Anket Maddeleri } & 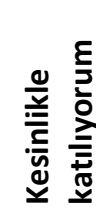 & 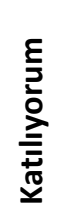 & 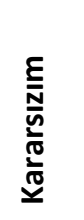 & 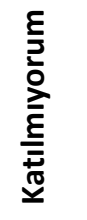 & 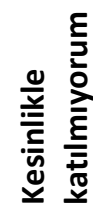 \\
\hline & $f$ & $f$ & $f$ & $f$ & $f$ \\
\hline & $\%$ & $\%$ & $\%$ & $\%$ & $\%$ \\
\hline \multirow{2}{*}{$\begin{array}{l}\text { 6- Oynadığım dijital oyunlarda sözlü komutları konuşurken } \\
\text { kullanıyorum. }\end{array}$} & 66 & 68 & 70 & 39 & 7 \\
\hline & 26.4 & 27.2 & 28.0 & 15.6 & 2.8 \\
\hline \multirow{2}{*}{$\begin{array}{l}\text { 7- Yurtdışı oyun sağlayıcılarından (server) diğer oyuncularla, } \\
\text { dilinde iletişim kurmak için konuşma programlarını kullanıyorum. }\end{array}$} & 24 & 60 & 57 & 59 & 47 \\
\hline & 9.6 & 24.0 & 22.8 & 23.6 & 18.8 \\
\hline \multirow{2}{*}{$\begin{array}{l}\text { 9- Oynadığım dijital oyunlarda duyduğum kelimelerin telaffuzlarını } \\
\text { tekrar edemiyorum. }\end{array}$} & 16 & 38 & 58 & 89 & 42 \\
\hline & 6.4 & 15.2 & 23.2 & 35.6 & 16.8 \\
\hline \multirow[t]{2}{*}{ 10- Sesli komut gerektiren () dijital oyunlar oynuyorum. } & 49 & 74 & 66 & 42 & 16 \\
\hline & 19.6 & 29.6 & 26.4 & 16.8 & 6.4 \\
\hline
\end{tabular}

Ankete katılan öğrencilerin \%28 i oyunlardaki sözlü komutları normal konuşmada kullanma konusunda kararsız olduğunu belirtirken, konuşma programları (chat) kullandığını söyleyen öğrenciler, kullanmayan öğrenciler ve kararsız öğrencilerin de yüzdelerinin birbirine yakın olduğu gözlenmiştir. Analiz sonuçlarına göre öğrencilerin sesli komut gerektiren oyunları da tercih ettikleri ve bu oyunları oynarken gerekli sesli tekrarları da yapabildikleri görüşü ortaya çıkmaktadır.

3.4. Dijital Oyunların, Kelime Yazma Becerisine Katkısına Yönelik Ortaöğretim Öğrencilerinin Görüşleri

Tablo 10 'da araştırmaya katılan öğrencilerin yazma becerisine yönelik anket maddelerine verdikleri cevapların frekans ve yüzdeleri verilmiştir. 
Tablo 10

Öğrencilerin Yazma Becerisine Yönelik Anket Maddelerine Verdikleri Cevapların Yüzdeleri

11- Dijital oyunlardaki bazı kelimelerin ekranda yazıyor

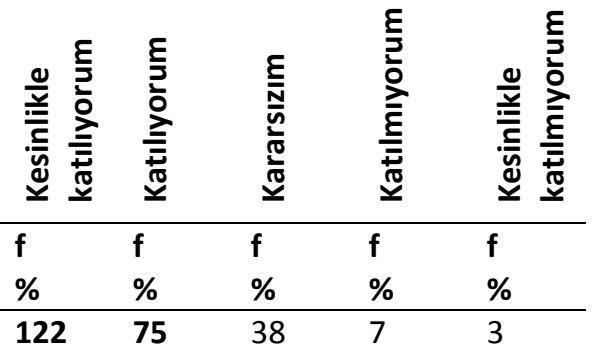

olması o kelimenin nasıl yazıldığını öğrenmeme katkı sağlıyor.

\begin{tabular}{|c|c|c|c|c|c|}
\hline & 48.8 & 30.0 & 15.2 & 2.8 & 1.2 \\
\hline \multirow{2}{*}{$\begin{array}{l}\text { 12- Dijital oyunlardaki kısaltmaların ne anlama geldiğini oyun } \\
\text { içinde öğrenebiliyorum. }\end{array}$} & 94 & 87 & 47 & 15 & 4 \\
\hline & 37.6 & 34.8 & 18.8 & 6.0 & 1.6 \\
\hline \multirow{2}{*}{$\begin{array}{l}\text { 13- Önceden yanlış yazdığım İngilizce kelimenin doğru } \\
\text { yazılışını dijital oyun esnasında görüp öğrendiğim oluyor. }\end{array}$} & 87 & 93 & 50 & 10 & 9 \\
\hline & 34.8 & 37.2 & 20.0 & 4.0 & 3.6 \\
\hline \multirow{2}{*}{$\begin{array}{l}\text { 14- Dijital oyunlar oynarken diğer oyuncularla yazarak iletişim } \\
\text { kurabildiğim yazma programlarını (chat) kullanıyorum. }\end{array}$} & 52 & 55 & 58 & 51 & 31 \\
\hline & 20.8 & 22.0 & 23.2 & 20.4 & 12.4 \\
\hline \multirow[t]{2}{*}{ 15- Dijital oyunlarda yeni öğrendiğim kelimeleri not alıyorum. } & 15 & 25 & 58 & 68 & 80 \\
\hline & 6.0 & 10.0 & 23.2 & 27.2 & 32.0 \\
\hline
\end{tabular}

Araştırmaya katılan öğrencilerin \%80 ine yakını oyun esnasında kelimenin ekranda yazıyor olmasının o kelimeyi öğrenmesinde olumlu etkisi olduğunu belirtmiştir. Ayrıca öğrencilerin büyük çoğunluğunun oyun içindeki kısaltmaları anlayabildiğini tespit edilmiştir. Oyun esnasında geçen kelimelerin öğrenciler tarafından çoğunlukla not edilmediği ortaya çıkmıştır.

\subsection{Dijital Oyunların, Kelime Okuma Becerisine Katkısına Yönelik Ortaöğretim Öğrencilerinin Görüşleri Nelerdir?}

Tablo 11 'de araştırmaya katılan öğrencilerin okuma becerisine yönelik anket maddelerine verdikleri cevapların frekans ve yüzdeleri verilmiştir.

Tablo 11

Öğrencilerin Okuma Becerisine Yönelik Anket Maddelerine Verdikleri Cevapların Yüzdeleri

\begin{tabular}{|c|c|c|c|c|c|}
\hline \multirow[t]{3}{*}{ Anket Maddeleri } & 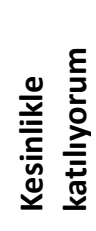 & 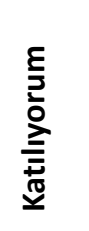 & $\begin{array}{l}\frac{E}{N} \\
\frac{N}{5} \\
\frac{\sqrt{0}}{\frac{\pi}{0}} \\
\frac{1}{2}\end{array}$ & 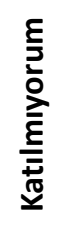 & 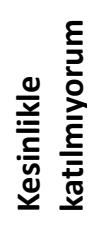 \\
\hline & $f$ & $f$ & $f$ & $f$ & $f$ \\
\hline & $\%$ & $\%$ & $\%$ & $\%$ & $\%$ \\
\hline \multirow{2}{*}{$\begin{array}{l}\text { 16- Dijital oyunlar oynarken ekranda yazan kelimeleri } \\
\text { okuyabiliyorum. }\end{array}$} & 104 & 119 & 28 & 4 & 3 \\
\hline & 41.6 & 44.0 & 11.2 & 1.6 & 1.2 \\
\hline \multirow{2}{*}{$\begin{array}{l}\text { 17- Dijital oyunlardaki kelimelerin görsel grafikle desteklenmesi o } \\
\text { kelimeyi okumama katkı sağlıyor. }\end{array}$} & 99 & 96 & 42 & 6 & 4 \\
\hline & 39.6 & 38.4 & 16.8 & 2.4 & 1.6 \\
\hline
\end{tabular}




\begin{tabular}{llllll}
\hline 18- Dijital oyunlar oynarken altyazıları anlayamıyorum. & 13 & 21 & 74 & 93 & 47 \\
& 5.2 & 8.4 & 29.6 & $\mathbf{3 7 . 2}$ & 18.8 \\
\hline $\begin{array}{l}\text { 19- Dijital oyunları sık oynayınca aynı kelimeleri sık okumak kelimeyi } \\
\text { öğrenmeme katkı sağlıyor. }\end{array}$ & $\mathbf{8 9}$ & $\mathbf{1 0 4}$ & 37 & 10 & 7 \\
& $\mathbf{3 5 . 6}$ & $\mathbf{4 1 . 6}$ & 14.8 & 4.0 & 2.8 \\
\hline $\begin{array}{l}\text { 20- Oyun oynarken ekranda okuduğum bilinmeyen kelimenin } \\
\text { anlamı için dijital sözlük kullanıyorum. }\end{array}$ & 28 & 48 & $\mathbf{7 1}$ & 49 & 53 \\
& 11.2 & 19.2 & $\mathbf{2 8 . 4}$ & 19.6 & 21.2 \\
\hline
\end{tabular}

Araştırmaya katılan öğrencilerin \%85.6' sı oyun esnasındaki kelimeleri okuyabildiğine dair olumlu görüş belirtmiştir. Ayrıca öğrencilerin çoğunluğu görsel olarak kelimenin anlamının destekleniyor olmasının kelimeyi daha anlaşılır yaptığını, alt yazıları anlayabildiklerini sık oynamanın öğrenmeye katkısı olduğunu görüşünü belirtmiştir. Ancak, öğrenciler yeni okudukları bir kelimenin anlamı için sözlük kullanma konusunda karasız ya da olumsuz görüş ifade ettikleri gözlenmiştir.

\subsection{Ortaöğretim öğrencilerinin dijital oyunların kelime öğrenimine katkısına ilişkin görüşlerinin cinsiyete göre değişimi}

Tablo 12 ' de araştırmaya katılan öğrencilerin, dijital oyunların kelime öğrenimine katkısına ilişkin görüşlerinde cinsiyete bağlı bir farklılık olup olmadığına dair yapılan t-testi sonuçları verilmiştir. İstatistiksel olarak aralarında anlamlı fark bulunan maddeler aşağıda Tablo13' de yer almaktadır.

Tablo 12

Anket Maddelerinin Cinsiyete Göre t- Testi Sonuçları

\begin{tabular}{|c|c|c|c|c|c|c|c|c|}
\hline & Cinsiyet & $\mathbf{N}$ & Ortalama & $\begin{array}{l}\text { Standart } \\
\text { Sapma }\end{array}$ & d & $\mathbf{t}$ & $\mathbf{p}$ & Anlamlı Farklılık \\
\hline \multirow[b]{2}{*}{3} & kadın & 96 & 4.0625 & .90394 & 244 & 2.367 & .019 & $p<.05$ \\
\hline & erkek & 150 & 3.7800 & .91864 & & & & \\
\hline \multirow[b]{2}{*}{6} & kadın & 99 & 2.6364 & 1.14691 & 248 & 2.593 & .010 & $p<.05$ \\
\hline & erkek & 151 & 2.2649 & 1.08137 & & & & \\
\hline \multirow{3}{*}{7} & kadın & 98 & 3.4898 & 1.18622 & 245 & 3.151 & .002 & $p<.05$ \\
\hline & erkek & 149 & 2.9799 & 1.28120 & & & & \\
\hline & kadın & 96 & 3.5521 & 1.23859 & 244 & 4.132 & .000 & $p<.05$ \\
\hline \multirow[t]{2}{*}{8} & erkek & 150 & 2.8533 & 1.32800 & & & & \\
\hline & kadın & 99 & 3.1919 & 1.19247 & 245 & 3.777 & .000 & $p<.05$ \\
\hline 14 & erkek & 148 & 2.5608 & 1.34633 & & & & \\
\hline
\end{tabular}

Tablo 12 incelendiğinde, Mersin ili, Silifke ilçesinden seçilen 3 (üç) farklı okul türünde okuyan 250 öğrenciye uygulanan anket sonuçlarına göre, öğrencilerin dijital oyunların kelime öğrenimlerine katkılarına yönelik görüşleri, aşağıda verilen 3. 6. 7. 8. ve 14. soru maddelerinde cinsiyete göre anlamlı bir farklılık göstermektedir.

1., 2., 4., 5., 9., 10., 11., 12. ve 13. soru maddelerine verilen cevaplara göre ortaya çıkan öğrenci görüşlerinde cinsiyete bağı farklılık görülmemiştir. 


\subsection{Ortaöğretim öğrencilerinin dijital oyunların kelime öğrenimine katkısına ilişkin görüşlerinin okul türüne göre değişimi}

Tablo 13' de araştırmaya katılan öğrencilerin, dijital oyunların kelime öğrenimine katkısına yönelik görüşlerinde okul türüne bağlı bir farklılık olup olmadığına dair sonuçlar verilmiştir. Sorular ve okullara göre anlamlı farklılık olan gruplar aşağıda verilmiştir.

Tablo 13

Anket Maddelerinin Okul Türüne göre ANOVA Sonuçları

\begin{tabular}{|c|c|c|c|c|c|c|c|}
\hline & $\begin{array}{l}\text { Varyans } \\
\text { Kaynağı }\end{array}$ & $\begin{array}{l}\text { Kareler } \\
\text { Toplamı }\end{array}$ & $d$ & $\begin{array}{l}\text { Kareler } \\
\text { Ortalaması }\end{array}$ & $f$ & Sig. & Anlamlı Farklılık \\
\hline \multirow{3}{*}{1} & Gruplar Arası & 7.619 & 2 & 3.809 & \multirow[t]{3}{*}{5.659} & \multirow[t]{3}{*}{.004} & Meslek - \\
\hline & Grup İçi & 165.594 & 246 & .673 & & & Anadolu \\
\hline & Toplam & 173.213 & 248 & & & & Anadolu - Özel \\
\hline \multirow{3}{*}{3} & Gruplar Arası & 19.574 & 2 & 9.787 & \multirow[t]{3}{*}{12.619} & \multirow[t]{3}{*}{.000} & Meslek - \\
\hline & Grup İçi & 188.463 & 243 & .776 & & & Anadolu \\
\hline & Toplam & 208.037 & 245 & & & & Özel - Meslek \\
\hline \multirow{3}{*}{4} & Gruplar Arası & 7.174 & 2 & 3.587 & \multirow[t]{3}{*}{4.455} & \multirow[t]{3}{*}{.013} & Meslek - Özel \\
\hline & Grup İçi & 198.890 & 247 & .805 & & & Anadolu - Özel \\
\hline & Toplam & 206.064 & 249 & & & & \\
\hline \multirow{3}{*}{5} & Gruplar Arası & 5.194 & 2 & 2.597 & \multirow[t]{3}{*}{3.134} & \multirow[t]{3}{*}{.045} & \multirow[t]{3}{*}{ Anadolu-Özel } \\
\hline & Grup İçi & 204.650 & 247 & .829 & & & \\
\hline & Toplam & 209.844 & 249 & & & & \\
\hline \multirow{3}{*}{6} & Gruplar Arası & 8.242 & & 4.121 & \multirow[t]{3}{*}{3.345} & \multirow[t]{3}{*}{.037} & \multirow{3}{*}{$\begin{array}{l}\text { Meslek - } \\
\text { Anadolu }\end{array}$} \\
\hline & Grup İçi & 304.322 & 247 & 1.232 & & & \\
\hline & Toplam & 312.564 & 249 & & & & \\
\hline \multirow{3}{*}{8} & Gruplar Arası & 17.930 & 2 & 8.965 & \multirow[t]{3}{*}{5.197} & \multirow[t]{3}{*}{.006} & Meslek - \\
\hline & Grup İçi & 419.163 & 243 & 1.725 & & & Anadolu \\
\hline & Toplam & 437.093 & 245 & & & & Meslek - Özel \\
\hline \multirow{3}{*}{11} & Gruplar Arası & 12.928 & 2 & 6.464 & \multirow[t]{3}{*}{8.370} & \multirow[t]{3}{*}{.000} & Meslek - Özel \\
\hline & Grup İçi & 186.885 & 242 & .772 & & & Anadolu - Özel \\
\hline & Toplam & 199.812 & 244 & & & & \\
\hline \multirow{3}{*}{16} & Gruplar Arası & 4.505 & 2 & 2.252 & \multirow[t]{3}{*}{3.540} & \multirow[t]{3}{*}{.030} & \multirow[t]{3}{*}{ Anadolu - Özel } \\
\hline & Grup İçi & 156.515 & 246 & .636 & & & \\
\hline & Toplam & 161.020 & 248 & & & & \\
\hline \multirow{3}{*}{19} & Gruplar Arası & 7.851 & 2 & 3.925 & \multirow[t]{3}{*}{4.341} & \multirow[t]{3}{*}{.014} & Meslek - Özel \\
\hline & Grup İçi & 220.660 & 244 & .904 & & & Anadolu - Özel \\
\hline & Toplam & 228.510 & 246 & & & & \\
\hline & Gruplar Arası & 14.059 & 2 & 7.029 & 4.361 & .014 & Meslek - Özel \\
\hline 20 & Grup İçi & 396.496 & 246 & 1.612 & & & Anadolu - Özel \\
\hline & Toplam & 410.554 & 248 & & & & \\
\hline
\end{tabular}

5., 6., 8., 11., 16., 19. ve 20. maddelerde istatistiksel olarak anlamlı bir farklılık olduğu görülmektedir.

2., 7., 9., 10., 12., 13., 14., 15., 17. ve 18. soru maddelerine verilen cevaplara göre ortaya çıkan öğrenci görüşlerinde, okul türüne bağı farklılık görülmemiştir.

\subsection{Dijital oyun oynayan ortaöğretim öğrencilerin oyunlardan en çok edindikleri} kelime grubu

Tablo 14 'te araştırmaya katılan öğrencilerin, oynadıkları dijital oyunlardan akıllarında en çok kalan kelimelerin neler olduğuna dair verdikleri cevapların sonuçları verilmiştir. 
Tablo 14

Cevapları

Öğrencilerin Dijital Oyunlardan Akıllarında En Çok Kalan Kelimelerin Neler Olduğuna Dair

\begin{tabular}{|c|c|c|}
\hline Kelime Türü & $\begin{array}{c}\text { Kelime Sayısı } \\
f\end{array}$ & Yazılan Kelime Örnekleri \\
\hline İsim & 351 & $\begin{array}{l}\text { Level, Ability, Power, Settings, Duration, Ready, World, Team, } \\
\text { Criminal, Champion, Exhabition, Option, Key, Kingdom, Mission, } \\
\text { Engine, Customer, Speed, Race, Player, etc. }\end{array}$ \\
\hline Sifat & 235 & Good,Fast, Easy, Perfect, Funny, Delicious, Strange, Missing, etc. \\
\hline Fiil & 110 & $\begin{array}{l}\text { Play, Start, Resume, Replay, Try, Support, Finish, Go, Stop, Buy, } \\
\text { Win, Restart, Add, Feed, Pass, Help, Lose, Load, Continue, Skip, } \\
\text { Move, etc. }\end{array}$ \\
\hline Cümle & 34 & $\begin{array}{l}\text { Are you ready? } \\
\text { Can you hear me? } \\
\text { You win. } \\
\text { Follow me. } \\
\text { Let's go. } \\
\text { Start a new game. }\end{array}$ \\
\hline Bağlaç & 7 & And, But, By the way, Then \\
\hline Edat & 5 & On, In, At \\
\hline Zamir & 3 & You, I, Mine \\
\hline Belirteç & 2 & The, $A / A n$ \\
\hline
\end{tabular}

Araştırmaya katılan öğrencilerin, 'Oynadığınız dijital oyunlardan aklınızda en çok kalan İngilizce kelimeler nelerdir?'sorusuna verdikleri cevaplar derlenmiş ve frekansları alınmıştır. Buna göre; öğrencilerin kelime gruplarından en çok isimleri hatırladıkları ortaya çıkmıştır. İkinci sırada ise sıfatları hatırladıkları görülmektedir. Eylem bildiren kelimelerin hatırlanma durumu üçüncü sırada yer almaktadır. Kelimelerin çeşitliliği oynadıkları oyunun içeriğine göre değişiklik göstermektedir. Kelimelerin yanı sıra öğrenciler bazı kelimeleri cümle içinde hatırladıklarını belirtmişlerdir. Cümle kalıplarının bu şekilde akılda kaldığı görülmektedir. Öğrencilerin kelime gruplarına verdikleri örnekler derlendiğinde en sık yazılan kelime örnekleri yukarıdaki tabloda verilmiştir.

3.9. Ortaöğretim öğrencilerinin dijital oyunlarda karşılaştıkları kelimeleri derslerinde ya da iletişimde kullanıp kullanmadıklarına yönelik görüşleri

Tablo 15 'de araştırmaya katılan öğrencilerin, dijital oyunlarda karşılaştıkları kelimeleri derslerinde ya da iletişimde kullanıp kullanmadıklarına dair görüşlerine yer verilmiştir.

Tablo 15

Öğrencilerin Dijital Oyunlarda Karşılaştıkları Kelimeleri Kullanıp Kullanmadıklarına Dair Görüşleri

\begin{tabular}{|c|c|c|}
\hline & Olumlu Görüş Belirten Öğrenciler & Olumsuz Görüş Belirten Öğrenciler \\
\hline $\begin{array}{l}\text { Öğrenci } \\
\text { Sayısı }\end{array}$ & 150 & 54 \\
\hline Görüşleri & $\begin{array}{l}\text { - } \\
\text { Arkadaşlar arası iletişimimi } \\
\text { - } \quad \text { Konuşma etkinliklerinde işime } \\
\text { yarıyor. } \\
\text { - } \quad \text { Aynı dijital oyunu oynamak } \\
\text { arkadaşlarımla benzer kelimeleri } \\
\text { bilmemize yardım ediyor. }\end{array}$ & 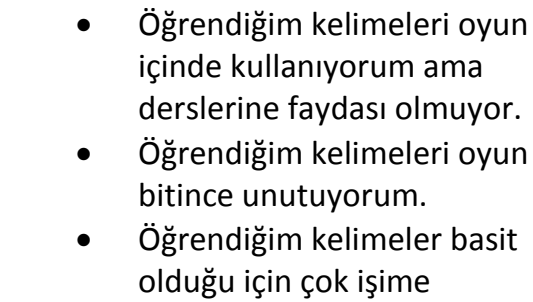 \\
\hline
\end{tabular}




\begin{tabular}{|c|c|c|}
\hline & 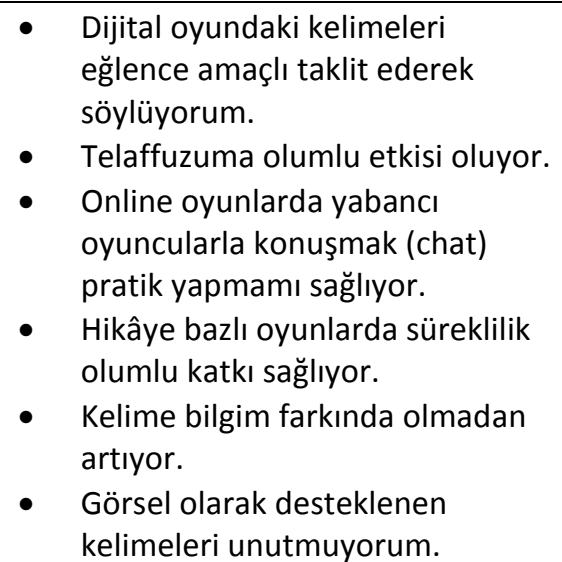 & yaramıyor. \\
\hline
\end{tabular}

Araştırmaya katılan öğrencilerin 'Dijital oyunlarda karşılaştı̆̆ınız kelimeleri İngilizce derslerinde ya da İngilizce iletişimde kullanıp ilişkilendirebiliyor musunuz?' sorusuna verdikleri cevaplar değerlendirildiğinde 150 öğrencinin olumlu görüş belirttiği, 54 öğrencinin ise olumsuz görüş belirttiği görülmüştür. Sonuçlara göre öğrencilerden alınan görüşlere ait ifadeler yukarıdaki belirtilmiştir. Araştırmaya katılan öğrencilerden $46^{\prime}$ sı aynı soruya herhangi bir yorum yapmamış, fikir beyan etmemiştir.

\section{SONUÇ, TARTIŞMA VE ÖNERILER}

Araştırmada elde edilen sonuçlara göre, örnekleme ait her sınıf düzeyindeki ortaöğretim öğrencilerinin dijital oyunlarla iç içe oldukları tespit edilmiştir. Araştırmaya katılan öğrencilerin \%70 'e yakınının internet bağlantısına sahip olduğunu göz önüne aldığımızda dijital ortamlara ve oyunlara ulaşımın daha kolay olduğu görülmektedir. Ortaöğretim düzeyindeki öğrencilerin aileleri dijital alışkanlıkların olumsuz yönlerine odaklansa da artık teknolojik gelişmelerin ve ortamların kaçınılmaz olduğunu fark etmektedirler. Ebeveynlerin çocuklardan beklentileri genellikle kitap okumak, şiir yazmak gibi entelektüel etkinliklerdir (Brody, 1993). Ancak, her şeyin dijitalleştiği bir dünyada sadece günlük yaşantımızda kullandığımız araçlar değil, çocuklar ve çocukların hayat şekilleri de dijitalleşme yönünde bir dönüşüme uğramıştır. Bu yüzden değişimin kaçınılmaz olduğu günümüzde yeni neslin alışkanlıklarını değerlendirirken empati kurmak daha doğru bir yaklaşım olacaktır.

Araştırmaya katılan öğrencilerin \%17.6' sı haftada en az 6 saat dijital oyun oynadığını ifade etmiştir. McGonigal (2010), dijital oyun kültürünün güçlü olduğu bir coğrafyada yaşayan bir gencin 21 yaşına kadar yaklaşık 10.000 saat çevrimiçi oyun oynadığını ifade etmiştir. Haftada en az 1 saat oyunlara ayırdığını belirten öğrenciler, görüşleri sorulduğunda bunun sadece bilgisayar üzerinden düşündükleri süre olduğunu belirtmişlerdir. Yani bu sürenin daha da fazla olduğunu ifade etmişlerdir. Uzun süreler geçirilen dijital oyunların öğrencilerin hayatında oldukça geniş yeri olduğunu görerek bu süre öğrenme amaçlı etkinliklere dönüştürebilir.

Araştırmaya katılan öğrenciler oynadıkları dijital oyun türünü belirtirken en çok yarış (\%47.6) ve aksiyon/serüven (\%47.6) türünde oyunları tercih ettiklerini belirtirken bunları sırayla strateji(\% 40.8) ve spor (\%40.4) türündeki oyunlar takip etmiştir. Alan yazındaki çalışmalara benzer şekilde Media Analysis Laboratory (1998) en fazla tercih edilen oyun türünün aksiyonmacera türü olduğunu rapor etmiştir.Kendilerine verilen oyun seçeneklerinden en çok aksiyon ve yarış türünü tercih ettikleri görülen öğrencilerin görüşlerini belirtirken bu tür oyunlarda sesli komutların ve karakterlerin daha etkileyici olduğunu düşündükleri görülmüştür. Gerçeğe yakın karakterler, ses ve görüntü efektleri yeni teknolojilerle ilerlemekte ve bu sebepten dolayı dijital 
oyunlara olan ilgi her geçen gün artmaktadır (Brand, Knight ve Majewski, 2003). Tercih edilen oyunlarda bulunan karakterlerin yabancı dilde kullandıkları ifadeler bu bağlamda öğrencilerin kelime ve cümlelerle olan aşinalığını arttırmaktadır.

Oyun oynama nedenleri incelendiğindeayrıştıranlardanstres atma (\%72.8), zaman geçirme (\%72.4), sosyal iletişim (\%33.2) ve meydan okuma (32.8) seçeneklerinin öne çıktığı görülmektedir.Oynayanı eğlendirirken başarısını ödüllendirmesi, gelişim hissi vermesi ve sosyalleşme ihtiyacını karşılaması, aktif olarak katılınan, başarı tatmini veren bir süreç olması, kadınlara, aileye ve çocuklara yönelik olarak farklılaşması oyunların giderek daha fazla insana hitap etmesini sağlamaktadır (TTNET, 2008).

Ortaöğretim düzeyindeki öğrenciler üzerinde yapılan bu araştırmada ulaşılan sonuca göre; öğrenciler en çok akıllı telefon ( \%79.6) aracılığıyla oyun oynadıklarını belirtmişlerdir. Konuyla ilgili benzer araştırmalara bakıldığında, 2-14 yaşları arasındaki çocuklar arasında en popüler dijital etkinliğin dijital oyunlar olduğu görülmektedir. Bir çocuk ortalama 6 yaşında bilgisayardan, 10 yaşında ise telefondan oyun oynamaya başlar (Shuler, 2009). Günümüz şartlarında pek çok öğrencinin akıllı telefona sahip olması dijital oyunlara ulaşma kolaylığını da beraberinde getirmektedir.

Günümüzde öğrenenlerin neyi, nasıl öğrendikleri tamamen onlara özgü bir durumdur (Annetta, 2008). Araştırmaya katılan öğrencilerden olumlu görüş belirtenler, dijital oyunların kendilerine sunduğu esneklikten memnun olduğunu ve arkadaş çevresiyle aynı oyunu oynayarak aynı oyun dilini kullandıklarını belirtmişlerdir. Bunun da arkadaşlar arası iletişim ve kabul için önemli olduğunu vurgulamışlardır.

Eğitimde bilgisayar kullanımının yaygınlaşması ve bilgisayar oyunlarına olan ilginin artması, öğrenme ortamlarında bilgisayar oyunlarının faydalı olabileceği düşüncesini ortaya çıkarmıştır. Bu düşünceyle birlikte birçok eğitsel yazılım geliştirilmiştir (Güngörmüş, 2007). Mevcut eğitsel dijital oyunların yanı sıra öğrencilerin tercih ettikleri dijital oyunlarda da doğru yönlendirmeler yapılarak fayda sağlanabileceği fark edilmiştir. Oyunların bu denli ilgi çekici olması birçok kesim gibi eğitimcilerin de dikkatini çekmiştir. Bu düşüncenin bir sonucu olarak öğrenenlerin geleneksel öğrenme araçları yerine, dijital oyunları bir eğitim aracı olarak kullanma fikri yaygın bir araştırma konusu olmuştur.Eğitim teknolojisi sayesinde öğrenme ve öğretme faaliyetleri zevkli bir hale gelmektedir. Öğrenciler, bu ortamlarda isteyerek, oynayarak ve severek öğrenmektedirler (İ̧̧man, 2005). Çok farklı ve geniş bir yelpazede kullanılan oyunlarla ilgili gelecekte deneysel çalışmaların yapılması ve oyun yapımı sürecinde açık ve gizil öğrenme yaklaşımlarıyla tasarlanmasının önemli olduğu düşünülmektedir. Araştırmaya katılan öğrencilerin dijital oyunların kelime öğrenimlerine katkısına yönelik görüşlerinde, dil becerileri temel alındığında büyük oranda olumlu görüş belirttikleri gözlemlenmiştir. Oyunlardaki sesli komutları, karakterlerin konuşmalarını anlayabildiklerini; oyunlarda geçen kelimelerin görsel grafiklerle desteklenmesinin akılda kalıcılığı sağladığını; oyun esnasında duydukları kelimelerin telaffuzlarını tekrar edebildiklerini; oyun oynarken yazma programları kullanarak diğer oyuncularla iletişim kurabildiklerini; kelimelerin ekranda yazıyor olmasının okumalarını kolaylaştırdığını belirtmişlerdir. Dil becerilerinin kazanılmasında bahsedilen özelliklerin oldukça önemli yeri bulunmaktadır.

Öğrencilerin oyun esnasında oyundan uzaklaşmalarına neden olacak eylemleri kullanmadıkları da gözlemlenen davranışlar arasındadır. Örneğin öğrenciler bilmedikleri bir kelime ile karşılaştıklarında ayrı bir sözlük programı kullanmadıklarını belirtmişlerdir. Tekrar deneme yöntemiyle kelimenin anlamını tahmin etme yoluna gittiklerini belirten öğrencilerin yaparak yaşayarak öğrenme gerçekleştirdiği fark edilmiştir. 
Dijital oyunların avantajları kadar dezavantajları da bulunmaktadır. Yapılan araştırmada özellikle kız öğrencilerin oyunlardaki argo içeriklerden rahatsız oldukları görülmüştür. Elbette içeriği tamamen değiştirmek söz konusu değildir. Ancak burada dikkat edilmesi gereken nokta dijital oyunu eğitim sürecine doğru zamanda, doğru oranda, planlı ve belirli amaçlar doğrultusunda aktarmaktır. Tamamen bireyin kontrolünde olan ve onun tasarımınıza göre şekillenecek bir öğrenme ortamı, sanal bir dünya yaratmak tamamıyla bireyin elindedir. Bu noktadan hareket etmesi gereken eğitimcilerin dijital oyunların potansiyelini kullanmaları gerekmektedir. Dünya çapında oyunların evrenselleştiği ve alt yapılı tasarlandığı göz önüne alınırsa yabancı dil edinilmesinde oyunların varlığının yok sayılması mümkün görünmemektedir.

Hämäläinen ve arkadaşları (2006), 3-Boyutlu oyun çevrelerindeki işbirlikçi öğrenme üzerine yaptıkları araştırmada, bu tür oyunların öğrencileri işbirliği yapmaya ikna ettiği ortaya çıkmışır. Birlikte oynanan oyunların bu işbirliğini arttırdığını ve benzer oyunları oynayan öğrencilerin oyunlarda geçen kelimeleri kullanarak iletişim kurduklarını ankette verdikleri cevaplardan da anlaşılmaktadır.

Yapılan araştırmaya göre ortaöğretim öğrencilerin yarısından fazlası dijital oyunların kelime öğrenimine olumlu yönde katkısı olduğunu belirtmiştir. Elde edilen verilerin çözümlenmesinden, öğrencilerin teknoloji ve dijital oyunlara yakınlığı görülmektedir. Öğrenciler, farkında olarak ya da olmayarak edindikleri kelimelerin öncelikle diğer oyuncularla, daha sonrasında derslerinde ve iletişimde işe yaradığını belirtmişlerdir.

Dijital oyunlar eğitsel unsurlar ile birleştirilebilir. Prensky(2001) bu şekildeki yaklaşımı "Dijital Oyun Tabanlı Öğrenme" olarak adlandırmıştır. "Dijital oyun + eğitim" şeklinde tasarımlanan ortamlar geleneksel ortamlara göre öğrenenler için daha çekici, daha eğlenceli ve daha etkili olabilirler (Prensky, 2001). Dijital oyunlarla eğitim, öğrenme deneyimi sırasında eğlenceyi de sağladığı için eğlence ve eğitim ifadelerinin karşılığı olan "edu-tainment" kavramıyla ifade edilmektedir (Griffiths, 2002). Öğrencilerin büyük çoğunluğunun oyunları stres atma ve eğlence amacıyla oynadığını ifade ettiğini düşünürsek eğlence faktörünün eğitimin vazgeçilmez bir parçası olması gerektiği göz önünde bulundurulmalıdır.

Araştırma eğitsel dijital oyunların aksine öğrencilerin mevcut oynadıkları dijital oyunları temel aldığı için, öğrencilerin ilgilerini daha çok çekmiştir. Bu da gösteriyor ki öğrenciler, belli zaman aralı̆ı̆ında planlı şekilde yapılan dijital aktivite ya da oyunlardan ziyade kendi oynadıkları oyunların içindeki temalarla daha çok ilgilenmektedirler. Günümüzde dijital oyun sektöründeki gelişmelerde göz önüne alındığında her türde oyuna rastlanmaktadır. Mevcut oyunların eğitimciler tarafından da takip edilerek, işe yarayacağı düşünülen dijital oyunların eğitim sürecine dâhil edilmesinde öğrencinin motive edilmesinde önemli yer tutacağı gözlenmiştir.

Çalışma sonucunda elde edilen bulgulara paralel olarak yapılan öneriler şunlardır:

- Dijital oyunları sadece yabancı dil öğrenimine katkı sağlayabilecek bir araç gibi düşünmek yerine, planlama, hedef koyma, strateji oluşturma, eleştirel düşünme gibi becerilerin kazandırılmasında da önemli bir eğitim ve eğlence aracı olarak düşünmek gerekmektedir.

- Oyundan edinilen kelime öğreniminin kullanımını yaygınlaştırmak için oyunu temel alan aktivitelerle dil öğrenimi etkinlikleri zenginleştirilebilir.

- Dijital oyunlardan edinilen bilgilerin farklı alanlarda nasıl kullandığı konusunda disiplinler arası işbirliği yapılarak konu genişletilebilir ve geliştirilebilir.

- Bundan sonraki araştırmalarda dijital oyunların deneysel olarak öğretime katkısını arttıracak çalışmalar yapılabilir. 


\section{KAYNAKLAR}

Annetta, L. A. (2008) Video Games in Education: why they should be used and how they are being used. Theory Practice 47 (3):229-239.

Bavelier, D. (2012). Your brain on video games. TALKS-TED 2012. www.ted.com/talks/daphne_bavelier_your_brain_on_video_games (Erişim Tarihi: 2015, 15 Mayıs).

Balcı, A. (1985). Sosyal Bilimlerde Araştırma Yöntemleri. Ankara: Pegem yayınları

Brand, J.E., Knight, S.J. ve Majewski, J. (2003). The diverse worlds of computer games: $A$ content analysis of spaces, populations, styles and narratives. First level up digital games research conference, University of Utrecht, The Netherland.

Caillois, R. (2006).The game design reader, a rules of play anthology. London, England: The MIT Press

Caillois, R. (1957). Lesjeux et leshommes. Gallimard. (Oyunlar ve Erkekler). http://en.wikipedia.org/wiki/Game (Erişim Tarihi: 2015, 20 Nisan).

Durdu, P., Tüfekçi, A. ve Çağıltay, K. (2005). Türkiye'deki öğrencilerin bilgisayar oyunu oynama alışkanlıkları ve oyun tercihleri: ODTÜ ve gazi üniversitesi öğrencileri arası bir karşılaştırma. Eurasian Journal of Educational Research, 19, 66-76.

Çepni, S. (2010). Araştırma ve Proje Çalışmalarına Giriş. Üçyol Kültür Merkezi, Trabzon.

Erkuş, A. (2013). Davranış Bilimleri Iç̧in Bilimsel Araştırma Süreci. Seçkin Yayıncılık, Ankara.

Gee, J.P. (2007). What video games have to teach us about learning and literacy. New York: Palgrave.

Griffiths, M. D., (2002). The Educational Benefits of Video Games. Education and Health, 20(3), 47-51

Güngörmüş, G. (2007). Web tabanlı eğitimde kullanılan oyunların başarıya ve kalıcılığa etkisi. Yayımlanmamış Yüksek Lisans Tezi, Gazi Üniversitesi, Ankara.

Hämäläinen, R.,Manninen, T., Järvelä, S., \&Häkkinen, P. (2006). Learning to collaborate: Designing collaboration in a 3-D game environment. Internet and Higher Education, 9, 47-61.

Karasar, N. (2003). Bilimsel Araştırma Yöntemi. (12. Baskı). Ankara: Nobel Yayın Dağıtım

Kirriemuir, J. (2002). Video Gaming, Education and Digital Learning Technologies. DLib Magazine, 8(2).

Martin, B.(2007). Should Video Games Be Viewed As Art?, Video Games and Art, Intellect Books: The University of Chicago Press, Amerika.

McGonigal, J.(2010). Gaming can make a better World. TED TALKS 2010. www.ted.com/talks/jane_mcgonigal_gaming_can_make_a_better_world.html (Erişim Tarihi: 2015, 08 Nisan).

Nintendo,(2008). What is bigbrain Academy? www.bigbrainacademy.com/ds/what/index.html (Erişim Tarihi: 2015, 10 Nisan).

Özdamar, K. (1999). Paket Programlar ile Istatistiksel Veri Analizi (2.Baskı). Eskişehir: Kaan Kitabevi

Prensky, M. (2001). Digital Game-based Learning. New York: McGraw-Hill. 
Shuler, C. (2009). Advancing children learning in a digital age. The Joan Ganz Cooney Centerat SesameWorkshop.www.joanganzcooneycenter.org/wpcontent/uploads/2012/11/gamechanger-presentation.pdf (Erişim Tarihi: 2015, 10 Mayıs).

Steinkuehler, C., (2010). Video Games and Digital Literacies, Journal of Adolescent \& Adult Literacy, 61-63

Sümbüloğlu, V. ve Sümbüloğlu, K. (2000). Sağlık Bilimlerinde Araştırma Yöntemleri. Ankara: Hatipoğlu Yayınları

Tor, H.,\& Erden, O. (2004). Ilköğretim öğrencilerinin bilgi teknolojilerinden yararlanma düzeyleri üzerine bir araştırma.3(1), s.120-130.

TÜDOF (Türkiye Dijital Oyunlar Federasyonu). (2012) Türkiye ve Dünyada Dijital Oyunlar Sektörü Hakkında Genel Rapor. www.tudof.org/ (Erişim Tarihi: 2015, 26 Nisan).

Türk Dil Kurumu (2015). Büyük Türkçe Sözlük. www.tdk.gov.tr (Erişim Tarihi: 2015, 15 Nisan). 


\section{SUMMARY}

Since the beginning of $21^{\text {st }}$ century, technology has evolved into a more dynamic setting which allows the collaboration of tech-users who enjoy using and playing digital games. Digital games lead to creation of a new culture which has its own citizens and virtual environment. This issue grasps the attention of teachers and instructors. In literature, there are conducted some research which show that digital games may be one way to engage students in the learning process. Digital games are increasingly becoming widespread and influential, especially in foreign language learning. The aim of this study is to investigate the views of secondary school students on the contributions of digital games to their vocabulary knowledge in English. This research is a descriptive study examining the research questions based on the analysis of qualitative data. Data of the study were collected through questionnaire applied in six secondary school students (250 students) in Silifke, Mersin the academic year of 20142015. Expert opinions have been gathered for checking its validity.

According to this research, it appeared that secondary school students at each class level were intertwined with digital games. According to the results of this research on the students at the secondary education level, most of the students (79.6\%) reported that they were playing the games via their smartphones. When we look at similar research on the subject, it is seen that digital games are the most popular digital activity among children between 2 and 14 years old. In today's conditions, the fact that many students have a smartphone also brings the convenience of accessing digital games. The findings of this study indicate that students do not use the actions that will cause them to move away from the game during the game. For example, students stated that they did not use a separate dictionary program when they encountered a word they did not know. It has been noticed that students have indicated that they are going to attempt to guess the meanings of unknown words by retrying, learn by doing, by living. The results indicated that students mostly prefer racing and action / adventure type of games. It was found that digital games are usually played in order to spend free time and blow off steam. Most of students usually get through smart phones to play games and state a positive opinion that digital games contribute to their knowledge of English Vocabulary and communication in English. Digital game-lover students in this study indicated that digital games were satisfied with the flexibility they offered and that they used the same game language by playing the same game with their friends. They also emphasized the importance of communication and acceptance among friends. It has been observed that students who participated in the research have a positive opinion on the contribution of digital games to vocabulary learning. The voice commands in the games allow the characters to understand their conversations; the support of the words in the games with visual graphics makes it possible to keep it in mind; They can repeat the pronunciations of the words they hear during the game; They can communicate with other players by using chat programs while playing games; They make it easier to read if the words are written on the screen. Digital gaming has its disadvantages as well as its advantages. However, it's also important to transfer the digital game into the training process at the right time, in the right place, in a planned way and for certain purposes. Creating a learning environment -a virtual world entirely in the control of a person and created according to his design- is entirely individual.

Consequently, more than half of the secondary school students expressed that digital games contributed positively to vocabulary learning. The analysis of the data obtained shows that students are close to and familiar with technology and digital games. Students stated that the words they acquire, whether they are aware or not, are often used with other actors, later in their lessons and in communication. Unlike educational digital games, research has attracted more students' attention because students are based on digital games they currently play. This shows that the students are more interested in the planned activities in a certain period of time, or in the games themselves, than in digital activities or games. Nowadays, all kinds of games are seen in the developments in the digital game sector. It was observed that existing games were followed by the trainers and it was observed that the digital games appeared to be useful and important in motivating the students when they were included in the education process. 